slowly and pay the price in much lower future benefit flows.

b) Stem the decline and have the forestry sector of the industry stay at about its current level or increase slightly. The Canadian Forestry Service states that this can be done with a $\$ 100$ million a year increase in forest renewal funding.

c) Move more decisively into intensive forest management and increase the productivity of the nation's forests to capture a reasonable share of the increasing world market for forest products. This will involve increasing current expenditures by some $\$ 1100$ million in real terms over the next 10 years. Longer delay will increase the cost.

The Canadian Institute of Forestry recommends a decisive move into intensive foestry. It will enable Canada to build on one of its main strengths and capture a good portion of the forest's potential. The benefits include thousands of new jobs, doubling our forest products exports and a major increase in tax revenues. The increase in employment would be an early benefit while the others would build more slowly.

\title{
The Role of Forest Management in Improving the Economic Union and Development Prospects for Canada
}

\author{
A Brief to the Royal Commission \\ on the Economic Union and \\ Development Prospects for Canada
}

by

\author{
The Canadian Federation of Professional Foresters' Associations
}

\section{Introduction}

The Canadian Federation of Professional Foresters' Associations was formed in late 1.982 as an affiliation between the four provincial professional foresters' associations* plus the Canadian Institute of Forestery. The CFPFA represents the people who manage Canada's forest lands.

The purpose of the CFPFA is to provide a national voice for professional foresters. Membership in the five affiliated organizations totals 6150 , including Canada's 3930 registered professional foresters (RPF's). The terms of reference of the CFPFA are to:

- provide communication between the participating associations;

- present position papers on issues of national concern;

- represent professional foresters in the national "forestery constituency;"

- foster the development of professional foresters associations in provinces where they do not exist.

- Ordre des ingenieurs forestiers du Québec, Ontario Professional Foresters Association. Association of Registered Professional Foresters of New Brunswick. Association of British Columbia Professiona Foresters.
As professionals we have a responsibility to advise the government and public on all matters related to forest management and therefore welcome this opportunity to provide input into the Royal Commission.

Our brief makes no attempt to document the overriding importance of the forest industry to Canada's economy. This type of documentation has already been provided in numerous other briefs. We have simply provided recommendations or identified important matters relative to forest management in Canada under the four categories of issues to be addressed by the Royal Commission. If elaboration or backing of any of our points is required, we would be glad to provide it at the hearings.

Mr. Macdonald is to be commended for his reported commitment to tell Ottawa to "establish a higher priority for forests in general". We hope our brief will assist in this regard.

\section{Canada's Economic Future}

Canada is the world's largest exporter of forest products. World demand for forest products in general and Canada's forest products in particular is expected to increase over the next 20 years. Canada is efficient and competitive at harvesting trees and manufacturing forest products.
Because of our past neglect of forest renewal, our biggest constraints in taking advantage of future market expansion will be shortages of timber and reduced timber quality.

Modernization will continue to severely reduce employment in the harvesting and manufacturing sectors of the forest industry, which is currently one of the largest employers in the country. By intensifying our forest management efforts we could ensure future supplies of quality timber, thereby increasing exports and we could put many more people to work. Intensive forest management is highly labour intensive.

There must be a transfer of employment emphasis within the forest industry from the manufacturing and harvesting sectors to reforestation and forest stand tending. Such a shift would not only increase employment and improve the productivity and quality of our timber output; it would also alleviate the traditional seasonal nature of woods employment and offset localized employment problems which often exist in regions where forest management has been neglected.

Forestry has the potential to relieve regional economic disparity. Every region of Canada has major forestry potential. 
Developing each region's full forestry potential would mean sound, long-term economic stability and growth. The more intensively we manage our forests, the more jobs we create, the better quality timber we produce, and the greater volume of timber we grow.

High technology should not be an industrial goal in itself, rather it should be tied to traditional Canadian economic "winners" such as forestry. There is a need for application of advanced industrial technology and bio-technology in forestry. But using hi-tech to build on a strength such as forestry rather than trying to artificially impose highly technical, new and often very competitive industrial sectors onto our economy, we stand a better chance of gaining full benefits from both approaches.

The amount of money required to get forest management onto its feet is relatively small. An increase in annual funding by industry and the federal and provincial governments from the current $\$ 1$ billion to about $\$ 2$ billion over 10 years would allow us to double forest exports and create thousands of jobs. To put these figures in perspective, the required annual increase really only amounts to the cost of two helicopter plants, or last year's Canadair deficit, or $4 \%$ of the annual value of the forest industry's output. Funding from the government's side should originate from existing programs in less important sectors and from the offsetting effects on current social welfare programs.

The Commission's recommendations will have important implications for future generations. While forestry can provide many near-term jobs and other economic benefits, it is really a long-term solution to Canada's economic problems. We have to make a commitment now to manage our forests instead of exploiting them. We must decide that Canada will no longer put off forest renewal. Things are at a point where a key task will be the arousal of sufficient public, bureaucratic and political interest before the state of our forest mismanagement becomes desperate. At that late stage the deterioration may become irreversible in terms of our practical ability to deal with it or too costly for the govenmental and industrial players to handle it.

Our current reliance on short-sighted make-work schemes would, for the most part, be obviated if a full and proper program of forest management were implemented in every region of the country.

\section{National Institutions of Government}

Trees don't vote. Forestry is rurally based, but political power is concentrated in urban areas. Our political systems have failed to maintain the productivity of our forests which are held and managed in trust by government for the public owners. There is a need to develop a political power base for forestry.

A separate federal department of forestry should be created to provide forestry with its rightful political, legislative and bureaucratic stature and clout.
Canada needs a strong forest policy embodying such things as prompt reforestation, integrated resource management sustained yield and protection of the forest land base.

The distant planning horizon involved in forestry necessitates a commitment from governments to plan and budget on a longterm basis (5-year firm, 20-year tentative). Forestry must be viewed as a national commitment that transcends differences in political philosophies and as a long-term priority that goes beyond terms of elected governments.

\section{Federal/Provincial Responsibilities}

Forestry could act as the "model" for improving federal/provincial relations The two levels of government have equal economic stakes in forestry. Significant efforts are needed by both levels to get our forests in shape. Each side could partition off logical areas of responsibility, yet work in concert to ensure success. Use forestry to forge a resource improvement alliance between the provinces and Ottawa; a "pilot-project" to demonstrate a new approach to effective federal/provincial relations. The federal government through its new department of forestry could play a leadership role in developing a cooperative approach that would emphasize clear definition of roles, commitments and responsibilities.

To help effect better cooperation and communication in forestry between the federal and provincial governments, a Canadian Council of Forestry Ministers should be created.

Forest management practices on most federal lands (particularly national parks, Indian reserves and national defense properties) are atrocious. Not only is this situation a waste of the resource, but it also represents lost opportunities to provincial and territorial economies - not to mention local residents, in particular Indians. Other federal forestry efforts lag far behind the benefits received. The federal government must substantially increase its commitment to forestry as a show of good faith to the provinces and in order to put federal efforts on a level concomitant with revenues received from the forest sector. There is also urgent need to step up efforts to finalize the new generation of federal/ provincial forestry agreements.

The federal and provincial governments must get together to elevate and better coordinate forestry education, training and R\&D.

Forestry is or has the potential to be an important economic sector in every province and territory. At the present time only four provinces have statutes providing for registration and licensing of professional foresters. The importance of forestry as a profession should be fully recognized by statute in every part of Canada. Professional foresters are the primary managers of the largest land base of any social or economic sector in the country. The owners of almost all of this land base, the. people of Canada, deserve to have their lands managed by qualified and accountable professionals

\section{Labour-Business-Government Relations}

There is the potential in forestry for bringing together labour, business and government in a way that would benefit al three sectors (more jobs, increased timber supplies, higher profits, more tax revenue). The objective of proper forest management is endorsed by all three sectors and they have already shown they can work together in critical forestry situations (e.g. USA countervailing duty threat). The federal governlment, by emphasizing forestry and by making a conscious commitment to act as a catalyst, could set up a breakthrough in tripartite economic cooperation.

There is a need to bring together all sectors of the forestry constituency and both levels of government to develop and implement a public awareness program emphasizing a wise use (conservation) philosophy towards forestry in order to offset the present polarization between exploitation and preservation. 